\title{
PATIENT SATISFACTION ON NURSING CARE: THE CASE OF GYNECOLOGY AND OBSTETRICS CLINICS
}

\author{
Meltem Akbas ${ }^{1}$
}

\begin{abstract}
Nursing care is an effective factor to allow the quality of health care services to be at a desired level. The ethical principles of justice and honesty are important for improving the quality of nursing care and patient satisfaction. This study determined satisfaction levels for nursing care of patients hospitalized in gynecology and obstetrics clinics of different types of hospitals providing health care services. This is a descriptive and cross-sectional study. The sample consisted of 420 female patients hospitalized in gynecology and obstetrics clinics. The data were collected using the "Patient Socio-demographics Form" and "Newcastle Nursing Care Satisfaction Scale." The nursing care satisfaction level of the participants according to hospital were as follows: Hospital A 70.68 \pm 15.51 , Hospital B 70.65 \pm 15.17 , Hospital C $65.41 \pm 16.48$, Hospital D 71.39 \pm 14.66 , and in total $67.2 \pm 16.13$. There were statistically significant relationships between nursing satisfaction levels of participants based on the hospital, marital status, age, income level, and length of hospital stay. Satisfaction levels of the participants regarding nursing care were above average. While the satisfaction levels were similar based on hospitals, the satisfaction levels for the private hospital, training and research hospital, and university hospital were higher than that of the public hospital.
\end{abstract}

Keywords: nurse, care, satisfaction, ethics

\section{Satisfacción del paciente con el cuidado de enfermería: el caso de clínicas de ginecología y obstetricia}

Resumen: El cuidado de enfermería es un factor efectivo en lograr la calidad al nivel deseado en el servicio del cuidado de salud. Los principios éticos de justicia y honestidad son importantes para mejorar la calidad del cuidado de enfermería y la satisfacción del paciente. El presente estudio determina los niveles de satisfacción del cuidado de enfermería de pacientes hospitalizados en clínicas de obstétrica y ginecología de diferentes tipos de hospitales que proporcionan servicios de cuidado de salud. Se trata de un estudio descriptivo y transversal. La muestra consistió de 420 mujeres pacientes hospitalizadas en clínicas de obstetricia y ginecología. Los datos se recolectaron usando el "Formulario sociodemográfico de pacientes" y la "Escala de satisfacción de cuidado de enfermería de Newcastle". Los niveles de satisfacción de cuidado de enfermería de los participantes de acuerdo a cada hospital fueron los siguientes: Hospital A 70.68 \pm 15.51 , Hospital B 70.65 \pm 15.17 , Hospital C 65.41 \pm 16.48 ,

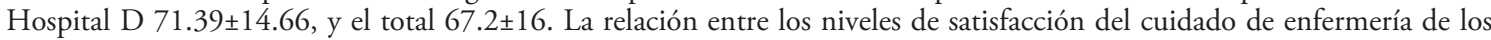
pacientes basado en el hospital, estado marital, edad, nivel de salario y duración de estadía en el hospital fue estadísticamente significativa. Los niveles de satisfacción de los participantes respecto a los cuidados de enfermería se encontraron por encima del promedio. Mientras que los niveles de satisfacción eran similares basándose en hospitales, los niveles de satisfacción de los hospitales privados, de entrenamiento, investigación y universitarios fueron mayores que los de los hospitales públicos.

Palabras clave: enfermería, cuidado, satisfacción y ética

\section{Satisfação do sobre cuidados de enfermagem: o caso daas clínicas ginecológicas e obstétricas}

Resumo: Cuidado de enfermagem é um fator importante para propiciar que a qualidade dos serviços de cuidados à saúde estejam em um nível desejado. Os princípios éticos de justiça e honestidade são importantes para melhorar a qualidade dos cuidados de enfermagem e a satisfação dos pacientes. Este estudo determinou os níveis de satisfação para cuidados de enfermagem de pacientes hospitalizadas em clínicas ginecológicas e obstétricas de diferentes tipos de hospitais que fornecem serviços de cuidados à saúde. Este é um estudo descritivo e de corte transversal. A amostra consistiu em 420 pacientes femininas hospitalizadas em clínicas ginecológicas e obstétricas. Os dados foram coletados utilizando-se o "Formulário Sócio-Demográfico do Paciente" e a "Escala de Satisfação com Cuidados de Enfermagem de Newcastle". O nível de satisfaçáo dos participantes com cuidados de enfermagem de acordo com o hospital foram os seguintes: Hospital A 70.68 \pm 15.51 , Hospital B 70.65 \pm 15.17 , Hospital

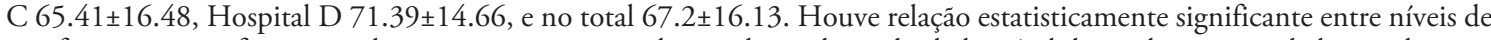
satisfação com a enfermagem dos participantes com o hospital, estado civil, idade, nível de renda e tempo de hospitalização. Níveis de satisfação das participantes com respeito aos cuidados de enfermagem estiveram acima da média. Enquanto os níveis de satisfaçáo foram similares entre os diferentes hospitais, os níveis de satisfaçáo para os hospitais privados, hospitais de treinamento e pesquisa, e hospitais universitários foram mais altos que aqueles dos hospitais públicos.

Palavras chave: enfermeira, cuidado, satisfação, ética

\footnotetext{
${ }^{1}$ Department of Midwifery, Faculty of Health Sciences, Cukurova University, Adana, Turkey Correspondence: makbaskanat@gmail.com
} 


\section{Introduction}

The evaluation of the quality of health care services is very important to improve the quality of health care services provided today, provide highquality health care services for all individuals, and enhance productivity of health care services (1-3). The most important determinant for evaluation of the quality of health care is the patient. The patient's view regarding the service provided and level of satisfaction are effective determinants of the quality of the service provided and allows adjustments to be made to provide improved services in accordance with the expectations of the patients $(1,2,4,5)$.

Patient satisfaction is defined as "the fundamental measure providing information on to what extent values and expectations of a patient are met and indicating the quality of the care in which the major authority is the patient" by Donabedian(6). Nursing care and the relevant satisfaction, however, were initially defined as "the harmony between ideal nursing care and the nursing care that a patient actually receives" by Risser in $1975(7,8)$. Patient satisfaction may vary depending on a variety of factors including physical and environmental conditions of a hospital, hospital staff, and features of a hospital(9). One of the most important factors influencing the satisfaction of hospitalized patients is the nursing care $(7,8,10)$.

Nursing is a profession whose field of interest is people and is based on care(1). The World Health Organization (WHO) defines nursing as "Nursing encompasses autonomous and collaborative care of individuals of all ages, families, groups and communities, sick or well and in all settings. It includes the promotion of health, the prevention of illness, and the care of ill, disabled and dying people"(11). Health care is fundamental for human growth and development and is a lifelong requirement for each individual. Health care is not only unique to nursing, but also specific for nursing. The distinctive feature of health care as nursing care is that it combines moral and emotional aspects of care with professional knowledge and skills and then reflects it to the nurse-patient relationship. As the care involves independent functions of a nurse and functions helping an individual feel better, it is an important fac- tor influencing satisfaction of hospitalized patients $(1,2,12)$. High-quality care is a right for all patients and is the responsibility of all nurses(13). Nursing practices should be based on scientific knowledge and skills, professional ethics, laws and obligations. This will ensure the protection of the rights and security of the individual and society served, and the limits of the duties, powers and responsibilities of the members of the profession(14). The guiding ethical principles in the moral decisions of nurses regarding care are benefit, harmlessness, respect for autonomy, and justice. The ethical principles of justice and honesty are important for improving the quality of nursing care and patient satisfaction $(14,15)$. Nursing care is an effective factor to allow the quality of health care services to be at a desired level. Thus, measurement of patient satisfaction is an important step when evaluating the quality of nursing care and health care services $(12,16,17)$. Patient satisfaction requires nurses to spend time with patients, talk to them, explain what to do, meet their needs within an acceptable timeframe, support their relatives and friends, and be helpful, competent, and qualified in their occupation(17). Nursing care patient satisfaction in gynecology and obstetrics clinics and nurses' awareness of the subject are not at desired levels. The data obtained from these evaluations identifies strong and weak aspects of nursing services and allows recognition of conditions that increase or prevent patient satisfaction, and necessary measures for increasing patient satisfaction can be taken $(10,17)$.

In studies conducted in the world and Turkey, the desired satisfaction level for nursing care of patients is seen. However, studies should be repeated periodically with different populations, hospitals, and clinics and databases should be established for taking necessary measures $(2-4,8,10,12,16-23)$.

This study is original because it was done in different types of hospitals and only in gynecology and obstetrics clinics.

\section{Research Questions}

What are the descriptive characteristics of patients?

What are the hospitalization characteristics of patients? 
What are the satisfaction levels with nursing care of patients hospitalized in gynecology and obstetrics clinics?

How do patient characteristics affect satisfaction levels with nursing care when hospitalized in gynecology and obstetrics clinics?

Aim

This study determined levels of satisfaction with nursing care of patients hospitalized in gynecology and obstetrics clinics of different types of hospitals providing health care services.

\section{Methods}

\section{Type of Study}

This study was descriptive and cross-sectional.

\section{Population and Study Sample}

The study was conducted in Adana province, which is located in the southern part of Turkey. The population of the study was 3871 patients who were hospitalized during a one-month timeframe in gynecology and obstetrics clinics of a university hospital (Hospital A), a training and research hospital (Hospital B), a maternity and children's hospital (Hospital C), and a private hospital (Hospital D). The sample size was calculated with the "National Statistical Service Sample Size Calculator". Sample number determined with a margin error of $5 \%$ and a confidence interval of $95 \%$ was 350 . Because data loss may occur in the study, the sample number was increased by $20 \%$. The study was planned for at least $420 \mathrm{pa}-$ tients and completed with 420 patients. For the sample, patients who were hospitalized in gynecology clinics of the defined hospitals for at least one day between the dates the questionnaire was applied, were about to be discharged from the hospitals, were 18 or older, could read and write in Turkish, had no medical obstacle to participate in the study, were conscious, and participated in the study voluntarily were included. Patients included in the sample were selected using the stratified random sampling method. Strata were formed according to number of patients admitted to the hospitals during 1 month (Table 1).

\section{Data Collection}

Data were collected between January 01-31, 2016 using the "Patient Identification Questionnaire" and "Newcastle Satisfaction with Nursing Care Scale (NSNCS)," which measures patient satisfaction with nursing care.

The "Patient Identification Questionnaire" was developed by the researchers' status, income level, education level, social security, employment status, history of previous hospitalizations, duration of hospitalization stay, and nursing care comparing the previous and current hospitalizations. The questionnaire included 11 questions about hospitalization location, gender, age, marital status, level of income, educational level, social security, status of employment, history of previous hospitalizations, duration of stay during the last hospitalization and improvement in regard to nursing care during previous and current hospitalizations.

The "Newcastle Satisfaction with Nursing Care Scale" was developed by Thomas et al. in 1996. Akın and Erdogan performed validity and reliability studies in Turkish in 2007(18). NSNCS is a 5-point Likert scale comprised of 19 items regarding nursing care. In the scoring used for sa-

\begin{tabular}{|c|c|c|c|}
\hline Hospital & $\begin{array}{c}\text { Total Number of } \\
\text { Patients Hospitalized }\end{array}$ & Patient Ratios (\%) & $\begin{array}{c}\text { Number of } \\
\text { Participating Patients }\end{array}$ \\
\hline Hospital A & 570 & 14.13 & 60 \\
\hline Hospital B & 554 & 14.13 & 60 \\
\hline Hospital C & 2342 & 59.5 & 250 \\
\hline Hospital D & 405 & 11.9 & 50 \\
\hline Total & 3871 & 100.0 & 420 \\
\hline
\end{tabular}

Table 1. Number of patients included in the sample using the stratified random sampling method (n: 420). 
Patient satisfaction on nursing care: the case of gynecology and obstetrics clinics - Meltem Akbas

\begin{tabular}{|l|l|l|}
\hline Characteristic & n & $\%$ \\
\hline Age & 151 & 36.0 \\
\hline$\leq 25$ & 180 & 42.9 \\
\hline $26-35$ & 89 & 21.2 \\
\hline$\geq 36$ & \multicolumn{2}{l|}{} \\
\hline Marital Status & 411 & 97.9 \\
\hline Married & 9 & 2.1 \\
\hline Single & \multicolumn{2}{l|}{} \\
\hline Educational Level & 60 & 14.3 \\
\hline Uneducated & 211 & 50.2 \\
\hline Primary school & 117 & 27.9 \\
\hline High school & 32 & 7.6 \\
\hline University and above & \multicolumn{2}{l|}{} \\
\hline Social Security & 363 & 86.4 \\
\hline Yes & 57 & 13.6 \\
\hline No & \multicolumn{2}{|l|}{} \\
\hline Employment Status & 371 & 88.3 \\
\hline Unemployed & 49 & 11.7 \\
\hline Employed & $\mathbf{4 2 0}$ & $\mathbf{1 0 0}$ \\
\hline Total & \multicolumn{2}{|l|}{} \\
\hline
\end{tabular}

Table 2. Percentage distribution according to descriptive characteristics of the patients (n: 420).

tisfaction level, the options are " 1 - Not satisfied at all, 2- Rarely satisfied, 3- Satisfied, 4- Very satisfied, and 5- Fully satisfied." Score evaluation is performed by summation of scores from all items in the scale. The maximum score obtainable is 95 and the minimum score is 19 . The total score determined for each patient was converted to a 100-point scale and then evaluated. A total score of 100 indicates all aspects of nursing care are satisfying. The Cronbach's alpha of the satisfaction scale is $0.96(18)$.

The researchers collected the questionnaires sealed in an envelope 30 minutes after they were delivered to the patients.

\section{Statistical Analysis}

Data were analyzed using IBM SPSS 20.0 (Statistical Package for the Social Sciences) program using descriptive and parametric statistical analysis methods. Descriptive statistical analyses involved calculation of means, standard deviations, frequencies, and minimum and maximum values. Comparisons were performed using a t-test for the comparisons of two groups and one-way ANOVA for the comparison of three or more groups. The statistical significance level was 0.05 .

\section{Ethical statement}

Approval from a University Faculty of Medicine Non-Invasive Clinical Research Ethics Committee was obtained on July 3, 2015 (44/39), and permission from the hospitals and informed consent from the patients participating in the study were obtained. Permission regarding the use of the Newcastle Satisfaction with Nursing Care Scale was obtained from Akın and Erdogan (18), who had conducted validity and reliability studies of the scale in Turkey.

Results

In table 2, descriptive characteristics of the patients are given. The mean age of the patients was $30.34 \pm 8.91,42.9 \%$ were within the age range of 26-35, $97.9 \%$ were married, $50.2 \%$ were primary school graduates, $88.3 \%$ were employed, and $86.4 \%$ had social security (Table 2 ). 


\begin{tabular}{|l|l|l|}
\hline Characteristic & n & $\%$ \\
\hline Hospital & 60 & 14.2 \\
\hline Hospital A & 60 & 14.3 \\
\hline Hospital B & 250 & 59.5 \\
\hline Hospital C & 50 & 12.0 \\
\hline Hospital D & \multicolumn{2}{l|}{} \\
\hline Previous Hospitalization History & 101 & 24.0 \\
\hline Once & 137 & 32.6 \\
\hline Twice & 98 & 23.3 \\
\hline Three times & 84 & 20.0 \\
\hline Four or more times & \multicolumn{2}{|l|}{} \\
\hline Hospital Stay Duration & 111 & 26.4 \\
\hline 1 day & 206 & 49.0 \\
\hline 2 days & 103 & 24.5 \\
\hline 3 or more days & \multicolumn{2}{|l|}{} \\
\hline Previous Hospitalization History in the Same Hospital & 319 & 76.0 \\
\hline Those hospitalized & 101 & 24.0 \\
\hline Those not hospitalized & $\mathbf{4 2 0}$ & $\mathbf{1 0 0}$ \\
\hline Total & \multicolumn{2}{|l|}{} \\
\hline
\end{tabular}

Table 3. Percentage distribution of patients' characteristics regarding status of hospitalization (n: 420).

The distribution of patients' characteristics regarding status of hospitalization is given in Table 3 . It was determined that $59.5 \%$ were hospitalized in Hospital C, 49.0\% were hospitalized for 2 days, $32.6 \%$ were previously hospitalized twice, and $76.0 \%$ were previously hospitalized at the same hospital (Table 3).

The mean NSNCS score was 67.6 \pm 16.13 (minmax: 21-100).

Table 4 shows the distribution of patient satisfaction level with the nurses. The patients stated they were least satisfied with the following nursing care practices: "the way the nurses made you feel at home" $7.9 \%$ (33), "how nurses listened to your worries and concerns" $6.9 \%(29)$, and "the way nurses explained things to you" $3.8 \%(16)$ (Table 4). On the other hand, the patients stated they were most satisfied with "the amount of privacy nurses gave you" $26.0 \%$ (109), "how often nurses checked to see if you were okay" $20.2 \%$ (85), and "how quickly nurses came when you called for them" $19.3 \%$ (81) (Table 4).
The distribution of patients according to characteristics of their mean satisfaction with nursing care scores is given in Table 5. When the mean NSNCS scores of the patients by hospital were examined, the mean score of the patients in Hospital A was $70.68 \pm 15.51$, in Hospital B was $70.65 \pm 15.19$, in Hospital C was $65.41 \pm 16.48$, and in Hospital D was 71.39 \pm 14.66 . The difference $(p=0.008)$ between the hospital in which the patient was hospitalized and satisfaction level of nursing care was statistically significant $(p<0.05)$. The mean NSNCS scores of the patients hospitalized in the private hospital were higher than in the other hospitals (Table 5).

When we examined the mean NSNCS scores by age of the patients, the difference between mean satisfaction with nursing care scores by age of the patients $(\mathrm{p}=0.000)$ was statistically significant $(p<0.05)$. As the age of the patients increased, their level of satisfaction also increased (Table 5).

When we examined the mean NSNCS scores by marital status, the difference $(\mathrm{p}=0.014)$ between marital status of the patients and mean NSNCS scores was statistically significant $(\mathrm{p}<0.05)$. Single 
Patient satisfaction on nursing care: the case of gynecology and obstetrics clinics - Meltem Akbas

\begin{tabular}{|c|c|c|c|c|c|}
\hline \multirow{2}{*}{ ITEMS OF SCALE } & 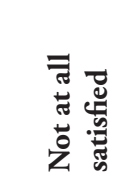 & 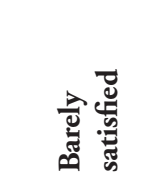 & 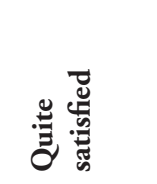 & 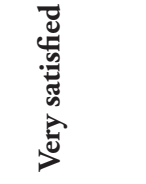 & 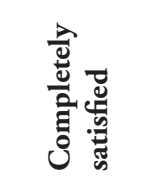 \\
\hline & $\%(n)$ & $\%(n)$ & $\%(n)$ & $\%(n)$ & $\%(n)$ \\
\hline $\begin{array}{l}\text { 1. The amount of time spent with } \\
\text { you }\end{array}$ & $3.3(14)$ & $16.2(68)$ & $41.0(172)$ & $24.0(101)$ & $15.5(65)$ \\
\hline $\begin{array}{l}\text { 2. How capable nurses were at their } \\
\text { job }\end{array}$ & $2.1(9)$ & $11.9(50)$ & $42.6(179)$ & $27.9(117)$ & $15.5(65)$ \\
\hline $\begin{array}{l}\text { 3. There always being a nurse } \\
\text { around if you needed on }\end{array}$ & $3.1(13)$ & $16.4(69)$ & $38.8(163)$ & $25.7(108)$ & $16.0(67)$ \\
\hline $\begin{array}{l}\text { 4. The amount nurses knew about } \\
\text { your care }\end{array}$ & $1.4(6)$ & $10.2(43)$ & $41.2(173)$ & $31.2(131)$ & $16.0(67)$ \\
\hline $\begin{array}{l}\text { 5. How quickly nurses came when } \\
\text { you called for them }\end{array}$ & $3.1(13)$ & $21.7(91)$ & $32.9(138)$ & $23.1(97)$ & $19.3(81)$ \\
\hline $\begin{array}{l}\text { 6. The way the nurses made you feel } \\
\text { at home }\end{array}$ & $7.9(33)$ & $28.3(119)$ & $32.6(137)$ & $16.9(71)$ & $14.3(60)$ \\
\hline $\begin{array}{l}\text { 7. The amount of information } \\
\text { nurses gave to you about your } \\
\text { condition and treatment }\end{array}$ & $3.1(13)$ & $14.0(59)$ & $39.0(164)$ & $28.8(121)$ & $15.0(63)$ \\
\hline $\begin{array}{l}\text { 8. How often nurses checked to see } \\
\text { if you were okay }\end{array}$ & $2.9(12)$ & $18.6(78)$ & $38.1(160)$ & $20.2(85)$ & $20.2(85)$ \\
\hline 9. Nurses' helpfulness & $1.9(8)$ & $8.3(35)$ & $41.2(173)$ & $31.7(133)$ & $16.9(71)$ \\
\hline $\begin{array}{l}10 \text { The way nurses explained things } \\
\text { to you }\end{array}$ & $3.8(16)$ & $13.8(58)$ & $38.8(163)$ & $28.8(121)$ & $14.8(62)$ \\
\hline $\begin{array}{l}\text { 11. How nurses helped put your } \\
\text { relatives' or friends' minds at rest }\end{array}$ & $3.1(13)$ & $21.2(89)$ & $38.8(163)$ & $22.9(96)$ & $14.0(59)$ \\
\hline $\begin{array}{l}\text { 12. Nurses' manner in going about } \\
\text { their work }\end{array}$ & $3.1(13)$ & $15.2(64)$ & $34.8(146)$ & $30.2(127)$ & $16.7(70)$ \\
\hline $\begin{array}{l}\text { 13. The type of information nurses } \\
\text { gave to you about your condition } \\
\text { and treatment }\end{array}$ & $2.9(12)$ & $15.0(63)$ & $37.9(159)$ & $30.5(128)$ & $13.8(58)$ \\
\hline $\begin{array}{l}\text { 14. Nurses' treatment of you as an } \\
\text { individual }\end{array}$ & $3.3(14)$ & $14.0(59)$ & $35.0(147)$ & $31.0(130)$ & $16.7(70)$ \\
\hline $\begin{array}{l}\text { 15. How nurses listened to your } \\
\text { worries and concerns }\end{array}$ & $6.9(29)$ & $20.0(84)$ & $35.7(150)$ & $21.7(91)$ & $15.7(66)$ \\
\hline $\begin{array}{l}\text { 16. The amount of freedom you } \\
\text { were given on the ward }\end{array}$ & $2.4(10)$ & $13.1(55)$ & $36.9(155)$ & $28.8(121)$ & $18.8(79)$ \\
\hline $\begin{array}{l}\text { 17. How willing nurses were to } \\
\text { respond to your requests }\end{array}$ & $3.6(15)$ & $14.8(62)$ & 36.7 (154) & 31.7 (133) & $13.3(56)$ \\
\hline $\begin{array}{l}\text { 18. The amount of privacy nurses } \\
\text { gave you }\end{array}$ & $1.2(5)$ & $8.6(36)$ & 32.9 (138) & 31.4 (132) & $26.0(109)$ \\
\hline 19. Nurses' awareness of your needs & $3.6(15)$ & $13.6(57)$ & $38.8(163)$ & $26.7(73)$ & $17.4(73)$ \\
\hline
\end{tabular}

Table 4. Percentage distribution of patient satisfaction with nursing care (n: 420). 
patients had higher mean NSNCS scores compared to those who were married (Table 5).

When we examined mean NSNCS scores by educational level of the patients, the difference $(\mathrm{p}=0.037)$ between educational level and mean NSNCS scores of the patients was statistically significant $(\mathrm{p}<0.05)$. Patients with educational levels of university or above had higher mean satisfaction with nursing care scores than other educational levels (Table 5).
When we examined the mean NSNCS scores by duration in the hospital, the difference $(\mathrm{p}=0.013)$ between the duration of hospital stay and the mean satisfaction with nursing care scores of the patients was significant $(\mathrm{p}<0.05)$. Mean satisfaction with nursing care scores of patients hospitalized for 3 or more days was higher than for shorter stays (Table 5).

No statistically significant difference was determined between status of having social security

\begin{tabular}{|c|c|c|c|c|c|c|}
\hline Characteristics & $\mathbf{n}$ & $\%$ & $\mathrm{M} \pm \mathrm{SD}$ & t value & F value & p value \\
\hline \multicolumn{7}{|l|}{ Hospital } \\
\hline Hospital A & 60 & 14.2 & $70.68 \pm 15.514$ & & \multirow[t]{4}{*}{3.983} & \multirow[t]{4}{*}{0.008} \\
\hline Hospital B & 60 & 14.3 & $70.65 \pm 15.197$ & & & \\
\hline Hospital C & 250 & 59.5 & $65.41 \pm 16.480$ & & & \\
\hline Hospital D & 50 & 11.9 & $71.39 \pm 14.669$ & & & \\
\hline \multicolumn{7}{|l|}{ Age } \\
\hline$\leq 25$ & 151 & 36.0 & $65.12 \pm 16.281$ & & \multirow[t]{3}{*}{9.146} & \multirow[t]{3}{*}{0.000} \\
\hline $26-35$ & 180 & 42.9 & $66.64 \pm 16.140$ & & & \\
\hline$\geq 36$ & 89 & 21.2 & $73.86 \pm 14.330$ & & & \\
\hline \multicolumn{7}{|l|}{ Marital Status } \\
\hline Married & 411 & 97.9 & $67.34 \pm 16.142$ & \multirow[t]{2}{*}{-2.473} & & \multirow[t]{2}{*}{0.014} \\
\hline Single & 9 & 2.1 & $80.70 \pm 8.885$ & & & \\
\hline \multicolumn{7}{|l|}{ Educational Level } \\
\hline Uneducated & 60 & 14.3 & $70.25 \pm 17.336$ & & \multirow[t]{4}{*}{2.849} & \multirow[t]{4}{*}{0.037} \\
\hline Primary school & 211 & 50.2 & $65.62 \pm 16.730$ & & & \\
\hline High school & 117 & 27.9 & $68.49 \pm 13.178$ & & & \\
\hline University and above & 32 & 7.6 & $72.76 \pm 18.129$ & & & \\
\hline \multicolumn{7}{|l|}{ Social Security } \\
\hline Yes & 363 & 86.4 & $67.74 \pm 15.484$ & \multirow[t]{2}{*}{0.370} & & \multirow[t]{2}{*}{0.712} \\
\hline No & 57 & 13.6 & $66.89 \pm 19.917$ & & & \\
\hline \multicolumn{7}{|l|}{ Employment Status } \\
\hline Unemployed & 371 & 88.3 & $67.44 \pm 15.90$ & \multirow[t]{2}{*}{-0.635} & & \multirow[t]{2}{*}{0.526} \\
\hline Employed & 49 & 11.7 & $69.0 \pm 17.909$ & & & \\
\hline \multicolumn{7}{|c|}{ Previous Hospitalization History } \\
\hline Once & 101 & 24.0 & $70.64 \pm 15.298$ & & \multirow[t]{4}{*}{1.817} & \multirow[t]{4}{*}{0.143} \\
\hline Twice & 137 & 32.6 & $65.90 \pm 17.179$ & & & \\
\hline Three times & 98 & 23.3 & $66.72 \pm 15.724$ & & & \\
\hline Four or more times & 84 & 20.0 & $67.86 \pm 15.564$ & & & \\
\hline \multicolumn{7}{|c|}{ Hospital Stay Duration } \\
\hline 1 day & 111 & 26.4 & $69.63 \pm 17.075$ & & \multirow[t]{3}{*}{4.393} & \multirow[t]{3}{*}{0.013} \\
\hline 2 days & 206 & 49.0 & $65.27 \pm 15.799$ & & & \\
\hline 3 or more days & 103 & 24.5 & $70.17 \pm 15.195$ & & & \\
\hline
\end{tabular}

Table 5. Distribution of patient characteristics and their mean satisfaction with nursing care scores (n: 420). 
$(\mathrm{p}=0.712)$, status of employment $(\mathrm{p}=0.526)$, and history of previous hospitalizations $(\mathrm{p}=0.143)$ and the mean satisfaction with nursing care scores (p>0.05) (Table 5).

\section{Discussion}

In a study conducted by Haile Eyasu et al.(4), $52.5 \%$ of the participants were satisfied with their nursing care. Tang et al.(10) found patients were moderately satisfied $(3.13 \pm 0.68)$ with the nursing care they received. In our study, the total mean patient NSNCS score was moderate (67.62 \pm 16.132$)$, similar to Haile Eyasu et al.(4), Ahmed et al.(23), Tang et al.(10) and Gecgil et al.(24). In contrast to our study, the satisfaction level of patients with preeclampsia in a study conducted by Uzun (20) was high.

The study indicated that the patients were least satisfied with the nursing practices "the way the nurses made you feel at home", "how nurses listened to your worries and concerns" and "the way nurses explained things to you", whereas they were most satisfied with "the amount of privacy nurses gave you", "how often nurses checked to see if you were okay" and "how quickly nurses came when you called for them" (Table 4). This suggests that nurses do not approach the patients holistically and they do not utilize psychologic and social aspects of nursing. The study by Akin and Erdogan(18) conducted to indicate the satisfaction level of patients with nursing care reported that respect for privacy is one of the nursing practices with which the patients are satisfied, which supports this study.

Kaya(20) reported the satisfaction levels of patients hospitalized in a maternity and children's hospital and a training and research hospital were higher than those hospitalized in a university hospital. In a study conducted by Bulut and Tashan(2), the satisfaction level of patients who had previous cesarean sections in a private hospital was higher than those who had them in other hospitals. In our previous study as well as the current study, the satisfaction level of patients hospitalized in a private hospital was higher than in other hospitals (Table 5).

In studies in which the satisfaction of patients with nursing care was evaluated, the level of satisfaction of the patients increased as their age increased $(3,16,18,19)$. Similarly, we found the difference $(\mathrm{p}=0.000)$ between the age of the patients and their mean satisfaction with nursing care was significant $(\mathrm{p}<0.05)$ and their level of satisfaction increased as their age increased (Table 5). Unlike our study, Haile Eyasu et al.(4) reported the satisfaction level of 18-30 year old patients was higher than for elderly patients. In a study conducted by Tang et al.(10), there was no significant difference in patient satisfaction between the patients over the age of $60(\mathrm{M}=2.12, \mathrm{SD}=0.60)$ and under the age of $60(M=2.19, S D=0.60)(p>0.05)$.

Educational level of patients may influence their satisfaction level with nursing care positively or negatively $(8,17)$. When examining other studies, some report increased educational level reduced level of satisfaction $(3,5,12,24)$. whereas others report educational level of patients did not influence their level of satisfaction with nursing care $(2,16,18,19,21,22)$. In our study, the difference $(p=0.037)$ between educational level of the patients and their mean satisfaction with nursing care was significant $(\mathrm{p}<0.05)$. The mean satisfaction with nursing care of patients with university degrees and above was higher than other educational levels (Table 5).

In parallel with our study, Bulut and Tashan(2) and Kaya(21) reported no significant differences between attendants' status of employment and health insurance and their levels of satisfaction with nursing care received (Table 5).

When the difference of patients' duration of hospital stay and their levels of satisfaction with nursing care was examined, Demir(16), Ozşaker and Kayrakci(3), and Kaya(21) reported no difference between duration of hospital stay and levels of satisfaction. In our study, however, level of satisfaction of the patients with a stay of 3 or more days was higher than with shorter stays (Table 5).

\section{Limitations of the Study}

The study is limited to patients hospitalized in Clinics of Gynecology and Obstetrics of four major hospitals of different types in Adana province. 


\section{Conclusion and recommendation}

In our study conducted in gynecology and obstetrics clinics, patient satisfaction with nursing care was moderate, and the patients stated that nurses did not approach them holistically and had a lack of spirituality. Patient satisfaction of those in the private hospital was higher than in state, university, and private specialty hospitals. Levels of satisfaction increased as patient age and educational level increased, and the levels of satisfaction of single patients were higher than those who were married. The levels of nursing care satisfaction of patients hospitalized for 3 or more days were higher than patients hospitalized for a shorter time.

According to these data, we recommend:

- Making necessary modifications after reviewing the contents of nursing education in terms of scientific knowledge and skills, professional ethics, laws and obligations.

- Organizing in-service training programs for graduate nurses based on satisfaction levels of the patients with nursing care.

- The administrators to develop a quality of life program to investigate and improve the work life quality of nurses.

- $\quad$ Providing a positive atmosphere in health care institutions to allow nurses to provide patients with better care.

- Conducting qualitative research about the factors influencing the quality of nursing care.

- Using periodic studies to determine patient satisfaction and the affecting factors.

\section{Implications for nursing management}

Patient satisfaction is based upon sufficiency of the provided service in meeting patients' expectations and perception of this service by the patients. In this regard, periodical measurement of patient satisfaction, which is an important indicator concerning nursing services, hence, health services, is important in determining the situations leading to dissatisfaction, finding appropriate solutions, making necessary regulations by nurses in practices concerning patient care and development of health care services.

Studies concerning patient satisfaction and determination of influencing factors, which were or will be conducted, can be used as a guide for planning and executing high-quality nursing care for nurses and head nurses.

\section{Acknowledgements}

We would like to thank all the participants in the study.

\section{Conflicts of Interest}

The authors declare no conflicts of interest with respect to the authorship and/or publication of this article.

\section{Funding}

The study was not supported any sponsorship.

\section{References}

1. Dinc L. Concept of care and moral dimension. Hacettepe University Journal of Nursing Faculty 2010; 17(2): 074-082. (In Turkish)

2. Bulut H, Tashan ST. Satisfaction of nursing care of caucasian women determination of levels. Inonu University Journal of Health Sciences 2017; 6 (1): 1-6. (In Turkish)

3. Özsaker E, Kayrakcı F. Determination of satisfaction levels of nursing care of surgical patients. Florence Nightingale Journal of Nursing 2014; 22(2): 105-113. (In Turkish) 
Patient satisfaction on nursing care: the case of gynecology and obstetrics clinics - Meltem Akbas

4. Haile Eyasu K, Adane AA, Amdie FZ, Getahun TB, Biwota MA. Adult patients's satisfaction with inpatient nursing care and associated factors in an Ethiopian Referral Hospital, Northeast, Ethiopia. Advances in Nursing 2016; (Article ID 6308617): 7 pages. do1: 10.1155/2016/6308617

5. Cerit B. Satisfaction level of patients with nursing care level of patients' satisfaction with nursing care. Hacettepe University Journal of Nursing Faculty 2016; 3(1). (In Turkish)

6. Donabedian A. Defining and measuring the quality of health care. Assessing Quality Health Care Perspectives for Cinicians 1992.

7. Merkouris A, Ifantopoulos J, Lanara V, Lemonidou C. Patient satisfaction: a key concept for evaluating and improving nursing services. Journal of Nursing Management 1999; 7(1): 19-28. do1: 10.1046/j.1365-2834.1999.00101.x

8. Yilmaz M, A measure of health care quality: patient satisfaction. Cumburiyet University Nursing School Journal 2001; 5(2): 69-74. (In Turkish)

9. Staniszewska, S, Laila A. The concepts of expectation and satisfaction: do they capture the way patients evaluate their care? Journal of Advanced Nursing 1999; 29(2): 364-372. do1: 10.1046/j.1365-2648.1999.00897.x.

10. Tang WM, Chi Yang, S, Wen CL. 2013. Patient satisfaction with nursing care: a descriptive study using interaction model of client health behavior. International Journal of Nursing Science 2013; 3(2): 51-56. do1:10.5923/j.nursing.20130302.04.

11. World Health Organization (WHO). Nursing. (cited 2016 November 23); Available from: http://www.who.int/topics/ nursing/en

12. Kuzu C, Ulus B. Determination of satisfaction with nursing care of patients treated at surgical clinics. Actbadem University Journal of Health Sciences 2014; 5(2): 129-134. (In Turkish)

13. Lynn MR, McMillen BJ, Sidani S. Understanding and measuring patients' assessment of the quality of nursing care. Nursing Research 2007; 56(3): 159-166. do1: 10.1097/01.NNR.0000270025.52242.70

14. Dinc L. The Importance of Ethics of Care for Nursing Practice. Turkiye Klinikleri Journal of Medical Ethics, Law and History-Special Topics 2017; 3(1): 1-9. (In Turkish)

15. Drumond JGDF. Ethics and health care quality. Philotecnia versus philanthropy. Acta Bioethica 2010; 16(2): 119-123.

16. Demir Y, Arslan G, Eser I, Khorsid L. Examining the level of satisfaction of patients in a training hospital for nursing services. Florence Nightingale Journal of Nursing 2011; 19(2): 68-76. (In Turkish)

17. Alhusban MA, Abualrub RF. Patient satisfaction with nursing care in Jordan. Journal of nursing management 2009: 17(6): 749-758. doi: 10.1111/j.1365-2834.2008.00927.x

18. Akin S, Erdogan S. The Turkish version of the newcastle satisfaction with nursing care scale used on medical and surgical patients. Journal of Clinical Nursing 2007; 16(4): 646-653.

19. Onsuz MF, Topuzoglu A, Cobek UC, Ertürk S, Yılmaz F, Birol S. The satisfaction level of patients in a medical school hospital in Istanbul. Marmara Medical Journal 2008: 21(1): 033-049.

20. Uzun G. In patients with mastectomy surgery, patients in the postoperative period nursing satisfaction and sociodemographic characteristics of the individual. Master Dissertation, Edirne, Turkey: Institute of Health Sciences Nursing Department; 2009. (In Turkish)

21. Kaya A. The determination of the satisfaction levels of nursing care obtained by the servants in the cesarean section. Master Dissertation. Konya: Selçuk University Graduate School of Health Sciences, Department of Nursing; 2011. (In Turkish)

22. Kol E, Arikan F, Ilaslan E, Akinci MA. Kocak MC. A quality indicator for the evaluation of nursing care: determination of patient satisfaction and related factors at a university hospital in the Mediterranean Region in Turkey. Collegian 2017;1-6. (cited 2016 November 23); Available from: http://ac.els-cdn.com/S1322769617300707/1-s2.0S1322769617300707main.pdf?_tid=ea651a50-988c-11e7-ae95 00000aab0f02\&acdnat=1505311845_191d62b6b8e 48f223151178f0ea37bbb).

23. Ahmed T, Assefa N, Demisie A, Kenay A. Levels of Adult Patients' Satisfaction with Nursing Care in Selected Public Hospitals in Ethiopia. International Journal of Health Sciences, Qassim University 2014; 8(4): 371-379.

24. Geckil E, Dundar O, Sahin T. Evaluation of patients' satisfaction levels from nursing care at the centre of the city Adryaman. Hacettepe University Journal of Nursing Faculty 2008; 15(2): 041-051. (In Turkish)

Received: November 23, 2018

Accepted: December 7, 2018 